\title{
Aikuiskasvatustoimijoiden mielikuvia tutkimuksen ja politiikanteon suhteesta ja vuorovaikutuksesta
}

\author{
Aikuiskasvatuksen tutkijoilla, käytännön toimijoilla ja \\ politiikantekijöillä on mielikuvia tieteenalalla tehtävän \\ tutkimuksen suhteesta politiikantekoon sekä näiden välisestä \\ vuorovaikutuksesta. Kun mielikuvia valaistaan toimijaverkkoteorian \\ käsitteillä, käy ilmi, että tutkimuksen ja politiikanteon vuorovaikusta \\ edistävät eritoten erilaiset välittäjät ja käsitteellisten kielten \\ kääntäminen, joka lisää jaettua ymmärrystä.
}

$\boldsymbol{y}$ AIKUISKASVATUKSELLA TARKOITETAAN sekä käytännön että tieteenalan toimintaa (Pantzar 2007; Suoranta, Kauppila \& Salo 2008, 21) eli aikuisia kansalaisia varten tehtävää ja heihin kohdistuvaa koulutus- ja kasvatustoimintaa sekä siihen liittyvää tutkimusta ja tieteellistä asiantuntijakoulutusta (Jarvis 2010). Kumpaakin ohjaa poliittis-hallinnollisen järjestelmän toiminta, johon ne myös osaltaan vaikuttavat muuttaessaan yhteiskuntaa enemmän tai vähemmän tarkoitushakuisesti (Heikkinen 2014).

Politiikanteko (policymaking) on prosessimaista, eri tasoilla tapahtuvaa vaikuttamistyötä ja päätöksentekoa toimintatapojen muuttamisen tar- peesta (Gorur 2010; Bridges \& Watts 2008; McLaughlin 2000). Siihen osallistuu poliitikkojen lisäksi monia toimijoita, kuten virkamiehiä, asiantuntijoita, edustajia ja vaikuttajaviestijöitä (McLaughlin 2000; van Zanten 2006). He ottavat kantaa sivistys-, kasvatus- ja koulutuspoliittisiin kysymyksiin joko tehtävänsä puolesta, prosessiin osallistettuina tai epäsuorasti esimerkiksi omilla kirjoituksillaan.

Aikuiskasvatuksen toimintakokonaisuuteen kytkeytyviä toimijoita voi karkeasti jaotella tutkijoiksi (researchers), käytännön toimijoiksi (practitioners) ja politiikantekijöiksi (policymakers). Toiminnoissa ja toimijuuksissa on kuitenkin päällekkäisyyksiä. 
Aikuiskasvatuksen toimijat eivät varsinaisesti muodosta verkostoa. Niillä on kuitenkin keskinäisiä, vuorovaikutukseen perustuvia suhteita, joita voi tarkastella joko yksi kerrallaan tai laajempina suhteiden kimppuina ja kietoutumina. Tässä artikkelissa otan tarkasteluun tutkimuksen ja politiikanteon suhteen ja vuorovaikutuksen. Sen lisäksi, että tutkijat ja politiikantekijät mieltävät suhteensa jonkin laatuiseksi ja määrittelevät sitä, myös muilla aikuiskasvatuksen toimijoilla on suhdetta koskevia mielikuvia.

Tutkijoiden mielikuviin tutkimuksen ja politiikanteon suhteesta ja vuorovaikutuksesta oletettavasti vaikuttavat heidän tulkintansa aikuiskasvatuksen tieteenalaluonteesta. Aikuiskasvatusta on pidetty pikemminkin käytäntöön suuntautuvana ja soveltavana tutkimusalana kuin omaan teoriaperustaan nojaavana perustieteenä (Heikkinen 2012; Jarvis 2010, 257 262; Usher \& Bryant 1989, 41-43). Sitä on asemoitu yhtäältä suhteessa yhteiskuntatieteisiin ja humanistisiin tieteisiin ja toisaalta suhteessa aikuiskasvatuksen käytäntöön ja politiikantekoon (Heikkinen 2014).

Tutkimuksen ja politiikanteon suhteesta tekee läheisen mutta jännitteisen se, että aikuiskasvatusta on käytetty instrumentaalisesti poliittisten intressien mukaiseen kansakunnan kulttuuriseen rakentamiseen ja työllisyystoimiin. Tutkijat taas ovat halunneet kehittää tieteenalaa sen omista lähtökodista käsin. (Heikkinen 2012; Nurmi \& Kontiainen 2000; Suoranta, Kauppila \& Salo 2008, 31; Heikkinen, Pätäri \& Teräsahde 2019.)

Politiikantekijöiden mielikuvat tutkimuksen ja politiikanteon suhteesta ja vuorovaikutuksesta ilmenevät ensinnäkin politiikka-asiakirjoista, joissa tutkimusta ohjataan yhteiskunnalliseen vaikuttavuuteen. Yliopistolaki (24.7.2009/558) märittää yliopistojen niin sanotuksi kolmanneksi tehtäväksi vuorovaikutuksen muun yhteiskunnan kanssa ja tutkimuksen yhteiskunnallisen vaikuttavuuden edistämisen. Tutkimuksen yhteiskunnallisen vaikuttavuuden mielletään ilmenevän useilla alueilla, joista politiikanteko on yksi tieteen kehittymisen, innovaatioiden luomisen, akateemisten ammattilaisten kouluttamisen ja julkisen keskustelun ja osallisuuden edistämisen ohella (Ylijoki, Lyytinen \& Marttila 2011; Alastalo, Kunelius \& Muhonen 2014).
Tieteenalakohtainen tarkastelu tutkimuksen suhteesta politiikantekoon ja vuorovaikutuksesta sen kanssa on kiintoisaa ja perusteltua, koska tutkijat muodostavat yhteisönsä yli institutionaalisten rajojen (Birnbaum 1988, 35-39). Yhteisöt määrittävät tieteenalalleen ominaiset tietämisen ja tiedontuotannon tavat sekä tutkimuksensa suhteen yhteiskuntaan.

Toiseksi politiikantekijöiden mielikuvat tutkimuksen ja politiikanteon suhteesta ja vuorovaikutuksesta ilmenevät siitä, miten politiikantekijät itse linjaavat hyödyntävänsä tutkimusta. Suomessa tutkimuksen hyödyntämisestä kasvatusta ja koulutusta koskevassa pätöksenteossa on keskusteltu enenevästi 2000-luvulta alkaen, jolloin muiden muassa Euroopan komissio ja taloudellisen yhteistyön ja kehityksen järjestö OECD linjasivat ohjelmissaan edistävänsä näyttöön perustuvaa (evidence-based) päätöksentekoa ja kehittämistä (Niemi 2017, 46).

Ajatus tutkimustietoon perustuvasta päätöksenteosta on 2020-luvulle tultaessa vahvistunut entisestään, ja se mainitaan esimerkiksi hallitusohjelman läpäisevänä periaatteena (VN 2019a, 11). Aikuiskasvatustutkimusta on esimerkiksi linjattu hyödynnettävän jatkuvan oppimisen uudistuksessa (OKM 2019a).

Tutkin tutkimuksen ja politiikanteon suhdetta ja vuorovaikutusta aikuiskasvatustoimijoiden jaettuina mielikuvina (imageries). Käytän mielikuvien käsitettä kasvatus- ja yhteiskuntatieteellisen tutkimuksen tapaan, eli pikemminkin niiden kollektiivisen luomisen merkityksessä kuin yksilöpsykologisina kognitioina (vrt. mental image). Englannin kielen imagery-termi voitaisiin suomentaa joko 'mielikuvaksi' tai 'mielikuvastoksi' (vrt. Alastalo ym. 2014).

Mielikuvien on määritelty olevan representaatioita ihmisten ajatuksista, käsityksistä, uskomuksista, kokemuksista, asenteista, tunteista ja arvostuksista (Manninen 2004). Niitä voi luoda ja jakaa vuorovaikutuksessa paitsi sanallisesti myös kuvallisesti, kuten metaforina (Väliverronen 2016, 67) sekä teorioina ja mallinnuksina (Alasuutari \& Quadir 2016). Mielikuvien ajatellaan suuntaavan vahvasti toimintaa (Eskola 2019; Alasuutari \& Quadir 2016; Manninen 2004). Kun pyritään muuttamaan jonkin asian tilaa, kannattaakin ensin tarkastella, mihin suuntaan ja miten toimijoiden jaetut mielikuvat ohjaavat toimintaa. 
Näin osataan paremmin valita keinoja, jotka johtavat toivottuun lopputulokseen.

Tutkimuskysymys kuuluu "millaisia mielikuvia aikuiskasvatuksen toimijoilla on tutkimuksen ja politiikanteon suhteesta ja vuorovaikutuksesta”?

Ensiksi esittelen, minkälaisia mielikuvia tutkimuksen ja politiikanteon suhteesta ja vuorovaikutuksesta sisältyy aiempaan tutkimuskirjallisuuteen. Sen jälkeen esittelen tutkimusmenetelmät ja aineiston, joiden avulla vastaan tutkimuskysymykseen. Lopuksi suhteutan aikuiskasvatustoimijoiden mielikuvia muuhun tutkimuskirjallisuuteen ja pohdin aikuiskasvatukselle ominaisia tutkimuksen ja politiikanteon vuorovaikutuksen keinoja ja suuntia.

\section{SUHTEIDEN AIEMPAA MALLINTAMISTA JA NÄYTTÖPERUSTEISEN POLITIIKANTEON KRITIIKKIÄ}

Kasvatustieteen tutkijat ovat suhtautuneet kriittisesti eritoten politiikka-asiakirjoista muodostuvaan mielikuvaan tutkimuksen ja politiikanteon suhteesta. Sen mukaan tutkimuksen tehtävä on tuottaa päätösten perustaksi näyttöä ja suosituksia siitä, mikä toimii ja on tehokasta (Biesta 2007, 2010; Locke 2009; Bridges \& Watts 2006, 42; Ness \& Gándara 2014, 259). Kasvatustieteiden mahdollisuutta tuottaa numeerisia faktoja politiikantekoa varten on pidetty ongelmalli- sena ensinnäkin, koska kasvatus perustuu ensisijaisesti arvoihin (Biesta 2007; 2010). Toisekseen toimintojen päämäärät, logiikat ja rytmit eroavat toisistaan. Tämä ilmenee muun muassa siten, että tutkimus jatkaa kysymysten asettamista silloinkin, kun vastauksia näyttäisi jo olevan, kun taas politiikanteossa pyritään pikemminkin pääsemään eroon kysymyksistä esittämällä ideologian pohjalta muotoiltua vastausta tukevaa näyttöä. (Lassnigg 2012, 180; 2016, 131.)

Näyttöön perustuvan politiikanteon diskursseja kriittisesti analysoineet David Hargreaves (1999) ja Lorenz Lassnigg (2012) ovat mallintaneet tutkimuksen, politiikanteon ja käytännön suhteita kolmiokuvioina. Mallien voi nähdä ilmentävän tutkijoiden mielikuvia toimintojen suhteista, vaikka samalla niiden esittäminen on poliittisen ohjauksen tuottamien mielikuvien kritiikkiä. Kolmion eri kulmiin sijoitettuina tutkimus, politiikanteko ja käytäntö näyttäytyvät erillisinä toiminnan alueina. Hargreavesin laatima malli (kuvio 1), jossa nuolet kulkevat yksisuuntaisesti, ilmentää, että tutkimus voisi vaikuttaa evidenssillä politiikantekoon ja käytäntöön suoraviivaisesti. Tutkimus ei kuitenkaan voi suoraan vaikuttaa politiikantekoon vaan voi lähinnä informoida sitä tehdystä tutkimuksesta (Hargreaves 1999, 246).

Lassniggin malli (kuvio 2), jossa nuolet kulkevat molempiin suuntiin kustakin kolmion kulmasta,

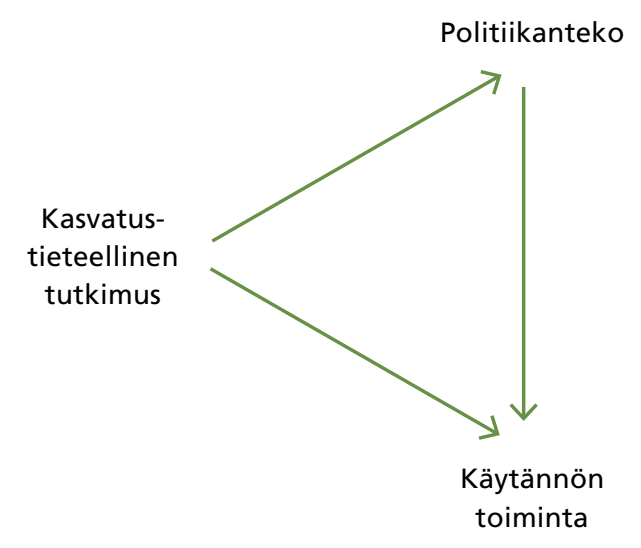

Kuvio 1

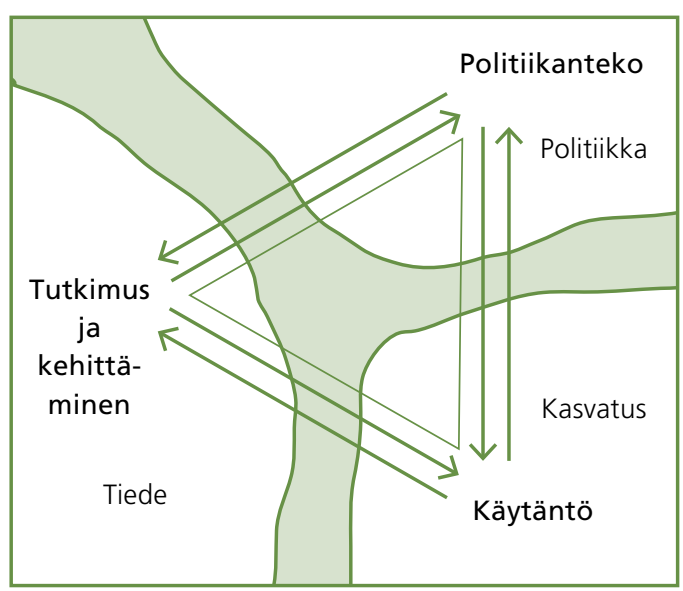

Kuvio 2

Tutkimuksen, politiikanteon ja käytännön suhteet Hargreavesin (1999) (kuvio 1) ja Lassniggin (2012) (kuvio 2) mukaan. 


\section{KOLMIOMALLINNUKSET EIVÄT}

\section{KUVAA VUOROVAIKUTUSTA.}

ilmentää taas sitä, että toimijat vaikuttavat vuoroin toisiinsa (Lassnigg 2012). Politiikantekijätkään eivät kuitenkaan voi suoraan vaikuttaa tutkimuksen aihevalintoihin ja pelkästään tilata tiedontarpeitaan palvelevaa tutkimusta, sillä laki takaa yliopistoissa tehtävälle perustutkimukselle autonomian. Kuvioista näyttävät siten puuttuvan ainakin välittäjät, jotka altistavat toimijat toistensa vaikuttamispyrkimyksille.

Välittäjiksi tutkijat ovat tunnistaneet esimerkiksi tutkimusohjelmat, tietokannat, tutkimusyhteenvedot, asiantuntijafoorumit sekä koulutustilaisuudet ja -ohjelmat (Locke 2009, 135-136). Tutkimuksen ja politiikanteon välimaastossa sijaitsee myös välittäjäorganisaatioita (intermediate organisation) (Lubienski, Scott \& DeBray 2014), kuten ajatuspajoja ja tutkimuskeskuksia (OECD 2007), jotka tuottavat niin kutsuttua politiikkatutkimusta (Scott 1999; OECD 2007, 16).

Toimijoiden vuorovaikutusta edistäviä välittäjärakenteita voidaan myös perustaa politiikanteon tai tutkimuksen rakenteisiin. Politiikanteon toimintaalueella sijainneesta välittäjärakenteesta esimerkkinä käy lainvalmistelua ja toimialan kehittämistä varten asetettu komitealaitos, jonka lakkauttamisen on katsottu johtaneen politiikantekoa tukevan tutkimuksen teettämisen vähenemiseen (Lampinen 2002). Yliopistoissa taas tehdään kumppanuustoimintaa ja perustetaan alustoja, ekosysteemejä ja yhteistyöverkostoja edistämään tutkimuksen, politiikanteon ja käytännön toimijoiden kohtaamista ja yhteistoiminnallista tutkimusta (esim. Nyman 2015).

Kolmiomallinnusten puute on se, että ne eivät kuvaa vuorovaikutusta. Kasvatus- ja yhteiskuntatieteissä toimijoiden vuorovaikutteisista suhteista puhutaan käsitteillä, kuten 'käyttäjien sitouttaminen' (user engagement) (Edwards 2012), 'yhteiskehittely' (co-creation) (Engeström 2004), 'tuottoisat vuorovaikutussuhteet' (productive interactions) (Spaapen \& van Drooge 2011; Muhonen, Benneworth \& Olmos-Peñuela 2019) ja 'yhteisluominen', jossa painottuu kestävyysnäkökulma (Trencher, McCormick, Doll \& Kraines 2014).
Toimintatutkimuksen perinteitä jatkavan, näyttöä tiettyyn tapaukseen hyödyntävän yhteistoimintatutkimuksen taustaoletukset ja menetelmät eivät suoraan ole siirrettävissä näyttöön perustuvaan politiikantekoon, jonka keskiössä ovat olleet tutkimustulosten suuntaa-antavuus ja yleistettävyys (Pawson 2006, 6). Tutkimuksen ja politiikanteon vuorovaikutus voi kuitenkin olla muutakin kuin näyttöön perustuvaa politiikantekoa. Siksi on tarpeen jatkaa tutkimusta nimenomaan tutkimuksen ja politiikanteon välisestä vuorovaikutuksesta tieteenalan ominaispiirteet huomioiden.

\section{TOIMIJAVERKKOTEORIA MATKAOPPAANA MIELIKUVIIN}

Sovellan tutkimuksessani toimijaverkkoteoriaa (actor-network theory, ANT) menetelmällisenä lähestymistapana toimijoiden mielikuvien analysointiin. Yksi ANTin luojista, tieteensosiologi Bruno Latour, on määrittänyt, että nimestään huolimatta ANT ei ole verkostojen analyysia (Latour 1999b, 15-19; Latour 2005, 132), ja on luonnehtinut sitä muun muassa "suhteiden sosiologiaksi" (Latour 2005, 9).

ANTin mukaan toimijan toimijuus riippuu tämän suhteista toisiin toimijoihin (Callon \& Latour 1981, 291-292; Latour 1996a, 86, 162; 1996b, 373; 2005, 46, 71), ja siksi ANT-tutkimus on kiinnostunut erityisesti toimijoiden tekemästä työstä suhteidensa määrittelemiseksi ja ylläpitämiseksi (Latour 1996b, 371). Tieteenteossa suhteita toisiin toimijoihin, luonnon ja teknologian toimijat mukaan lukien, voidaan määrittää joko erontekoina tai pyrkimällä ylittämään niitä, mitä Latour on käsitteellistänyt levittämismallin (diffusion model) ja käännösmallin (translation model) käsittein. Levittämismallissa painotetaan tieteen autonomiaa, ja tiedon oletetaan leviävän ja vaikuttavan yhteiskunnassa ilman vuorovaikutustakin (Latour 1987, 133-141; 1999a, 19, 97). Käännösmallissa taas ei eroteta tieteen sisä- ja ulkopuolisia toimijoita, vaan ilmiöitä ja uusia toimijoita tehdään tiedetyksi ja todeksi kollektiivisesti lukuisilla käännösten ketjuilla tutkimusprosessien eri vaiheissa (Latour 1987, 108121, 141-146, 157-159; 1999a, 20, 80, 97).

Käytän ANTia menetelmällisenä lähestymistapana siten kuin Latour itse ja muutamat muut tutkijat ovat 
K $\dddot{A}$ ÄNÖSMALLISSA

TIEDETT $\ddot{A}$ TEHD $\ddot{A} \ddot{N}$

KOLLEKTIIVISESTI JA

VUOROVAIKUTTEISESTI.

esittäneet: sen metakielen omaiset käsitteet ohjaavat tutkijaa analyyttisinä työkaluina matkaoppaan tapaan tekemään huomiota tutkimuskohteesta (Latour 1984; Latour 2005, 17, 30; Michael 2017, 3; Lehtonen 2015, 149; Thompson 2015; Teräsahde, tulossa). ANTin käsitteistö ei kuitenkaan lisää uusia selittäviä tekijöitä tutkimuskohteesta, vaan se ainoastaan sallii yhtenäisen tavan tuoda esille eri toimijoiden erilaiset käsitteellistykset (Ylikoski 2000, 297). ANTin käsitteillä jäsennän analyysiä siitä, minkälaisena aikuiskasvatuksen toimijat aineistossa mieltävät tutkimuksen ja politiikanteon suhteen ja minkälaisten keinojen he mieltävät estävän tai edistävän vuorovaikutusta.

Analyysia ohjaaviksi ANT-käsitteiksi olen valinnut 'mustat laatikot,' 'välittäjät', 'käännökset' ja 'intressit'. Toimijoilla on tapana rakentaa ympärilleen musta laatikko, kuten instituutio, suojatakseen kollektiivinsa olemassaoloa ja vahvistaakseen toimintaansa ja sen riippumattomuutta toisista toimijoista. Samalla vuorovaikutus mustan laatikon ulkopuolisiin toimijoihin vähenee (Callon \& Latour 1981, 285; Latour 1987, 128-137).

Välittäjät ovat asioita tai ihmisiä tai ei-inhimillisistä ja inhimillisistä elementeistä koostuvia hybridejä, kuten vuorovaikutusalustoja, jotka linkittävät toimijoita yhteen ja mahdollistavat vuorovaikutuksen toimijoiden lähtökohtaisesta erillisyydestä huolimatta (Latour 1993, 1-3; 1996a, 219; 1999a, 307; 2005, 39).

Käännöksiksi kutsutaan toimijoiden välistä neuvottelua intresseistä, jotka kohdistuvat tutkimukseen ja yhteistoimintaan (Callon \& Latour 1981, 279; Latour 1987, 108, 117; 1996a, 85-86). Intressien kääntämistä on esimerkiksi tutkijoiden pyrkimys kääntää erilaisia argumentointistrategioita käyttäen politiikantekijöiden ja muiden tutkimuksen rahoittajien tieteeseen kohdistuvia intressejä, jotta nämä antaisivat tukensa tieteen tekemiselle (Latour 1987, 108-121).
Käännösten tekeminen tutkimuksen ja politiikanteon vuorovaikutuksessa on siis aika ajoin suostuttelua ja voimien koetuksia (trials of strenghts) (Latour 1988, 214, 218). Käännökset merkitsevät myös työtä sen eteen, että esimerkiksi käytännön toimijat ja politiikantekijät kokisivat tutkimuksen relevantiksi. Kokemus tutkimuksen merkityksellisyydestä on omiaan lisäämään sen hyödyntämistä ja vaikuttavuutta (Latour 1987,$59 ; 2005,138)$.

\section{AINEISTOT JA ANALYYSI}

Aineisto kerättiin pääosin vuosina 2010-2011 "Aikuiskasvatuksen tutkimusyhteistyön rakenteelliset innovaatiot (AITURI)" -hankkeessa, jonka toteutti Aikuiskasvatuksen Tutkimusseura ry (Heikkinen \& Teräsahde 2011). Tätä tutkimusta varten laajemmasta aikuiskasvatuksen tutkimuksen, käytännön ja politiikanteon tutkimusyhteistyön kehittämistä koskevasta aineistosta olen rajannut analysoitavaksi ne osa-alueet, jotka ilmentävät informanttien mielikuvia tutkimuksen ja politiikanteon suhteesta ja vuorovaikutuksesta. Mielikuvat perustuvat osin toimijoiden omiin kokemuksiin mutta heijastavat myös ajatuksia, uskomuksia ja asenteita siitä, minkälaista vuorovaikutusta he pitävät mahdollisena tutkimuksen ja politiikanteon välillä.

Puolistrukturoituja avainhenkilöhaastatteluja tehtiin 11 . Niiden teemat olivat 1) esiymmärrys aikuiskasvatuksen tieteellisestä koulutuksesta, 2) käsitykset tutkimuksen, käytännön ja politiikanteon toimijoiden suhteista, 3) käsitykset aikuiskasvatustutkimuksen hyödyntämisestä politiikanteossa ja käytännössä, 4) kokemukset tutkimusyhteistyöstä, 5) käsitykset tutkimusyhteistyön kehittämisen tarpeesta ja 6) ehdotukset uusiksi käytänteiksi ja rakenteiksi tutkimusyhteistyön kehittämiseksi.

Haastattelut kestivät tunnista kahteen tuntiin. Niihin valikoitiin henkilöitä, jotka edustaisivat aikuiskasvatuksen erilaisia toimintoja ja toimijoita. Haastateltavia (liite 1) pyydettiin kertomaan paitsi omista näkemyksistään alan asiantuntijana myös puhumaan edustamansa toimijajoukon puolesta asiantuntija- tai esimiesasemansa tarjoamalta näköalapaikalta. Heidät jaoteltiin ensisijaisesti edustamansa toiminnan perusteella kolmeen ryhmään: tutkimus (3 henkilöä), 
käytäntö ( 6 henkilöä) ja politiikanteko ( 2 henkilöä). Jaottelu ei ole yksiselitteinen, eivätkä toimijuudet poissulje toisiaan.

Politiikantekijöiksi luokiteltiin haastatellut valtionhallinnon virkamiehet. Lisäksi esimerkiksi edunvalvontajärjestöissä työskentelevät käytännön toimijat osallistuvat politiikantekoon kuuluessaan edustuksellisiin työryhmiin. Moni politiikantekijä ja käytännön toimija teki samalla tutkimusta. Aineisto sisältää siten haastattelujen määrää suuremman määrän toimijapositioita. Avainhenkilöasemien ja päällekkäisten roolien vuoksi myös käytännön toimijoiden haastattelut ovat antoisia tutkimuksen ja politiikanteon suhdetta analysoitaessa, vaikka tutkimuksen ja käytännön suhteen tarkastelua on tässä yhteydessä jouduttu voimakkaasti rajamaan.

Ryhmäkeskusteluja oli kahdeksan, ja niihin osallistui 196 henkilöä (liite 1). Ne järjestettiin tutkijoiden ja käytännön toimijoiden tutkimus- ja kehittämispäivillä joko esitelmän tai työpajan yhteydessä. Osaan tilaisuuksista osallistui myös politiikantekijöitä. Viimeinen keskustelu järjestettiin hankkeen päätyttyä, vuonna 2014. Keskustelut vaihtelivat muodoltaan ja kestoltaan, mutta sisällöiltään niissä käsiteltiin samoja teemoja kuin haastatteluissa. Keskustelutilaisuuksien aineistoa analysoitiin samaan tapaan kuin haastatteluaineistoa. Avainhenkilöhaastattelujen edustuksellisuudesta ja ryhmäkeskusteluihin osallistuneiden henkilöiden lukumäärästä huolimatta aineistojen perusteella ei voi tehdä yleistyksiä.

Analysoin aineiston siten, että ensin luin ja koodasin sitä valitsemieni ANTin metakäsitteiden mukaisin koodein. Muodostin koodatusta aineistosta uusia temaattisia kokonaisuuksia. Ryhmittelin tematisoitua aineistoa edelleen alateemoihin. Laadin synteesiä alateema kerrallaan. Poimin aineistonäytteiksi sitaatteja, joissa kutakin teemaa määrittänyt ANT-käsite ilmeni kuvaavimmin.

\section{LÖYDÖKSIÄ AIKUISKASVATUSTOIMIJOIDEN MIELIKUVISTA}

ANT-käsitteet toimivat analyysissa matkaoppaina, mutta menetelmän käyttö tällä tavoin väistämättä rajaa myös sitä, mitä aineistosta voidaan löytää. Toisilla käsitevalinnoilla huomio olisi voinut kohdistua toisiin asiakokonaisuuksiin. Käsitteitä pidettiin kuitenkin vain lähtökohtana aineiston ryhmittelylle, ja tärkeää oli ANTin periaatteiden mukaisesti antaa toimijoiden puhua puolestaan (Latour 2005, 142-143). Löydösten esittäminen on siis tulosta tasapainoilusta niin sanotun teoria- ja aineistolähtöisen analyysin välillä.

\section{Vuorovaikutukseen kohdistuvia intressejä lähtökohtaisesta erillisyyden kokemuksesta huolimatta}

Useat haastatellut ja keskustelutilaisuuksiin osallistuneet aikuiskasvatustoimijat käyttivät ilmaisuja, joissa tutkimus ja politiikanteko, kuten myös aikuiskasvatuksen käytäntö, elivät omissa "maailmoissaan" tai "todellisuuksissaan", toimivat omanlaisellaan toimintalogiikalla ja käyttivät toisistaan eroavaa kieltä. Toimijoiden välinen vuorovaikutus oli vähäistä ja työteliästä.

Mielikuva, jota puhe ilmensi ja tuotti, vastasi ANTin mustan laatikon käsitteellistystä. Muutamien kokeneiden tutkijoiden ja käytännön toimijoiden mukaan tutkimuksen, politiikanteon ja käytännön toimijoilla oli joitakin vuosikymmeniä aiemmin ollut enemmän yhteistyötä ja kiinnostusta toistensa työhön. Mustien laatikoiden rakentamisella on siis ollut historiallinen kehityksensä aikuiskasvatustoimijoiden läheisistä suhteista kohti toimintakulttuurien eriytymistä ja institutionalisoitumista (ks. Heikkinen ym. 2019).

Paitsi tutkimuksessa, eriytymistä oli tapahtunut myös käytännön toiminnassa muun muassa vapaan sivistystyön ja ammatillisen aikuiskoulutuksen välillä sekä sen seurauksena, että aikuiskasvatusta koskeva hallinto oli hajautettu silloiselta opetusministeriön aikuiskoulutuksen tulosalueelta useisin yksiköihin. Eriytymisen koettiin monimutkaistaneen vuorovaikutusta.

Eroavaisuutta ja erillisyyttä korostavista mielikuvistaan huolimatta aikuiskasvatustoimijoilla oli odotuksina ja toiveina ilmaistuja mielikuvia aikuiskasvatustutkimuksen hyödynnettävyydestä politiikanteossa. Erityisesti vapaan sivistystyön toimijat odottivat aikuiskasvatustutkimuksen tuottavan toimintansa hyödyistä ja vaikuttavuudesta näyttöä, 


\section{ERITYISESTI VAPAASSA}

SIVISTYSTYÖSS $\ddot{A}$

TUTKIMUKSELTA ODOTETTIIN

\author{
N ̈̈ҮTTÖ̈̈, JOLLA VAIKUTTAA \\ POLITIIKANTEKOON.
}

jolla voisi vaikuttaa politiikantekoon. Näytöllä perusteltaisiin aikuiskoulutustoiminnan resursoinnin tarvetta ja osoitettaisiin, että resurssit on käytetty tehokkaasti ja tarkoituksenmukaisesti. Mielikuva tutkimuksesta evidenssin tuottajana politiikantekoa varten kiteytyi yhden vapaan sivistystyön toimijan kuvailuun:

"[--] niitä odotetaan, kuin kuuta nousevaa niitä tutkimuksia, mitkä hyödyttäis sitä omaa työtä ja jolla vois nimenomaan perustella sitä, miksi me ollaan tärkeitä ja miksi vapaata sivistystyötä tarvitaan ja miksi sitä täytyis sen takia resursoida, miksi sille tarvitaan rahotusta. Tämähän on se väylä, että yritetään perustella sitä rahotusta kunnassa, että me tarvitaan näin paljon rahaa ensi vuonna opiston toiminnan ylläpitämiseen, koska tämä on osoitettu tässä ja tässä tutkimuksessa näin tärkeäksi ihmisille, mitä vaikutuksia sillä on esimerkiksi johkin hyvinvointiin, jos sitä ei järjestetä.” (H5:69).

Mielikuvat politiikantekijöiden intresseistä hyödyntää aikuiskasvatustutkimusta päätöksenteossa vaihtelivat. Vaikka käytännön toimijat olivat itsekin esittäneet evidenssitutkimustoiveita, he olivat huolissaan, että politiikantekijät hyödyntävät lähinnä tilastotietoa. He toivoivat, että nämä olisivat kiinnostuneita tutkimuksesta laajemmin ymmärtääkseen entistä paremmin kasvatustoimintaa ja kehityskulkuja numeroiden takana ja perustaakseen päätöksensä tutkimustietoon. Niin käytännön toimijoiden mielikuvien kuin politiikantekijöiden kokemusten mukaan politiikantekijöiden intresseihin aikuiskasvatustutkimusta kohtaan vaikuttaa heidän yleinen asenteensa tiedettä kohtaan. Intressien syntymiseen on voinut vaikuttaa myös aiempi työkokemus tutkimuksen ja aikuiskoulutuksen parissa.
Näin asiaa kuvasi yksi politiikantekijä:

”Että se tietenkin lähtee pitkälti siitä, minkälainen asenne esimerkiksi virkamiehellä on tutkimukseen, suhtautuuko hän siihen sillai, et sitä voidaan hyödyntää vai ajatteleeko hän, että se on sellanen välttämätön paha. Mutta kyllä mä uskon, että sillä on merkitystä." (H7:49).

Tutkijoiden ja käytännön toimijoiden mielikuvat politiikantekijöiden intresseistä tutkimukseen näyttivät kapeammilta kuin näiden itsensä ilmaisemat. Yksi politiikantekijä toivoi tutkimustietoa, jota voitaisiin hyödyntää etsittäessä ratkaisuja aikuisten kansalaisten ura- ja koulutuspolkujen rakentamiseen yhteiskunnan ja työelämän muuttuessa sekä tutkimusta, joka valottaisi kasvatuksen ilmiöiden kehitystä historiasta tulevaisuuteen. Lisäksi politiikanteon tutkimusperusteisuutta oli pyritty vahvistamaan instituutiotasolla, mistä toinen politiikantekijä nosti esimerkiksi Opetushallituksen tutkimusstrategian (2010), jossa linjattiin tutkimuksen hyödyntämistä lisättävän.

Haastatteluissa ja keskusteluissa ilmeni, että tutkijoiden ensisijainen intressi oli politiikanteon tarpeisiin sitomaton, kriittinen perustutkimus ja että tutkijoiden omia intressejä voi olla vaikea sovittaa ulkoa tuleviin odotuksiin. Esimerkiksi aikuiskoulutusta koskevan tilastotiedon systemaattisen keruun aloittaminen oli kuitenkin tutkijan mukaan ollut aikanaan tutkijoiden ja politiikantekijöiden jaettu intressi, eli molemmat toimijat pitivät tilastotietoa hyödynnettävänä ja hyödyllisenä.

Käytännön toimijoiden mielikuvat tutkijan positiosta tutkimuksen ja politiikanteon vuorovaikutuksessa vaihtelivat. Yhden mukaan "erityisesti edunvalvoja tarvitsee sitä neutraalia tutkijaa" (H9:3), sillä hän mielsi, että neutraali tutkimustieto vakuuttaa politiikantekijät paremmin kuin edunvalvontaorganisaatioiden lobbaus. Käytännön toimijat kuitenkin toivoivat myös, että aikuiskasvatuksen tutkijat osallistuisivat poliittiseen keskusteluun ja puhuisivat sivistystyön puolesta, kuten yksi heistä ilmaisi:

”Joo, et vapaa sivistystyö ja tiede-elämä kaipaa sellasia vanhoja kunnon tiedeihmisiä, jotka on myös mukana käytännön politiikassa ja mun mielestä jos se katkeaa se yhteys, että tieteen ja politiikan 
välillä ei tää linkki toimi, ni sit täs on isoja ongelmia, että tarvitaan tällasia poliittisesti orientoituneita tiedemiehiä kyllä ja toivottavasti niitä kasvaa edelleen." (H6:179).

Tutkimuksen ja politiikanteon erillisyys ja tutkimuksen neutraalius näyttäytyivät siis positiivisessa valossa silloin, kun tutkimus ymmärrettiin näytön tuottamiseksi, mutta negatiivisessa silloin, kun tarvetta koettiin olevan perusteellisemmalle vuorovaikutukselle kasvatustoiminnan periaatteista ja edellytyksistä.

\section{Välittäjärakenteita tutkimuksen ja politiikanteon suhteessa}

Vuorovaikutukselle alustoja tarjoavina hybrideinä välittäjinä näyttäytyivät muiden muassa tutkimus- ja kehitysprojektit, tutkimusohjelmat, tilaustutkimus ja arvioinnit. Projektien nähtiin tuottavan tietoa, jolla on jokin yhteiskunnallinen tarve.

Yksi politiikantekijä kertoi, että projekti, jossa hän oli ollut mukana, oli ohjausryhmineen luonut alustan tutkijoiden, politikantekijöiden ja käytännön toimijoiden vuorovaikutukselle. Muillakin toimijoilla oli kokemuksia, että projektien käynnistys-, väli- ja päätösseminaarit kutsuivat eri toimijaryhmiä kuulemaan tutkimuksen tuloksista ja keskustelemaan niistä sekä jatkotutkimustarpeista ja politiikkatoimista. Euroopan unionin rahoittamissa projekteissa vuorovaikutuksen oli tullut ilmetä jo tutkimussuunnitelmasta, ja projektin sanottiin noudattaneen "konseptia", joka "automaattisesti huolehtii siitä, että ollaan yhteydessä" (H9:56). Samaan tapaan projekteina toteutetut arvioinnit ohjaus- ja toteutusryhmineen olivat muodostaneet vuorovaikutusta synnyttäneen välittään. Politiikantekijöillä miellettiin lisäksi olevan käytännön toimijoita paremmat mahdollisuudet hyödyntää tutkimusta teettämällä tiedon tarpeisiinsa vastaavaa, projekteina toteutettavaa tilaustutkimusta, joskin hallinnonkin resurssit ovat rajalliset. Tutkijat taas pitivät ongelmallisena sitä, että tilaustutkimusta hyödynnetään politiikanteossa enemmän kuin akateemista tutkimusta.

Tutkijoiden järjestämien konferenssien, seminaarien ja avoimien ovien päivien miellettiin samoin toimi- van vuorovaikutuksen alustoina. Yksi politiikantekijä ajatteli sekä kansallisten että kansainvälisten tutkimuskonferenssien tarjoavan hyvän keinon tutustua tieteelliseen keskusteluun, verkostoitua ja luoda kontakteja kasvokkaisissa keskusteluissa, mikä edistää myöhempääkin yhteistyötä. Hänen mielestään politiikantekijät voisivat useamminkin osallistua tutkimuskonferensseihin "koska tiedekeskustelu on vähän erilaista kuin ministeriössä tapahtuva keskustelu" (H7:6).

Hybridinä välittäjänä voidaan myös pitää kasvatusalan tiedelehtiä. Yksi politiikantekijä ja useat käytännön toimijat mainitsivat muun muassa Aikuiskasvatus-lehden linkkinä aikuiskasvatustutkimukseen. Lehden perustajiin kuuluneen tutkijan mukaan lehti oli pyrkinyt toimimaan sektorirajat ylittävänä keskustelufoorumina. Siinä oli myös julkaistu politiikantekijöiden ja käytännön toimijoiden puheenvuoroja. Niin ikään julkaisun toimituskunta muodosti yhden välityksen, kuten yksi toimituskuntaan kuulunut käytännön toimijoiden edustaja kuvaili. Hän kertoi toimituskunnan työhön osallistuessaan painottaneensa tiedeartikkelien yleistajuisuutta ja kiinnostavuutta. Politiikantekijä piti Aikuiskasvatuksen lukemista hyvänä keinona "päästä selville siitä, mitä [aikuiskasvatustutkimuksessa] tapahtuu" (H7:6). Hän myös koki avoimen julkaisemisen edistävän tiedon saavutettavuutta ja hyödynnettävyyttä.

Välittäviä rakenteita, kuten neuvotteluelimiä, voidaan luoda tutkimuksen ja politiikanteon toimintoihin huolehtimaan sidosryhmäyhteistyöstä, intressiryhmien edustuksellisuudesta päätöksenteossa ja päätöksentekoprosessien demokraattisuudesta. Useat avainhenkilöt mainitsivat silloisessa opetusministeriössä sijainneen, jo lakkautetun aikuiskoulutusneuvoston (2003-2006) esimerkkinä rakenteesta, joka oli tukenut tutkimuksen ja politiikanteon toimijoiden välistä vuorovaikusta. Neuvoston välittäjäluonnetta ilmensi sen kutsuminen "foorumiksi" ja "neuvottelukuntamalliksi": se oli ollut alusta toimijoiden väliselle keskustelulle ja aikuiskasvatusalan yhteistoiminnalliselle kehittämiselle. Neuvosto oli myös teettänyt tutkijoilla tutkimuksia ja selvityksiä. Pari haastateltavaa tosin suhtautui osittain kriittisesti siihen, miten neuvoston teettämä tutkimus vaikutti politiikantekoon; heidän mukaansa sitä ei varsinaisesti ollut hyödynnetty. 
MuUtamat toimijat

SUHTAUTUIVAT UUSIEN

RAKENTEIDEN LUOMISEEN

\section{PERIAATTEELLISEN}

KRIITTISESTI.

Haastateltavat mainitsivat myös aikuiskoulutusneuvoston jälkeen edustuksellisena välittäjätoimielimenä jatkaneen elinikäisen oppimisen neuvoston (2009-2011), joka sekin lakkautettiin.

Sekä tutkija että politiikantekijä toivat esiin, että 1970-luvulla välittäjärakenteena ministeriössä oli toiminut aikuiskoulutuskomitea (1971-1975). Se oli tarjonnut alustan toimijoiden väliselle vuorovaikutukselle ajankohtaisista yhteiskunnallisista ja koulutuspoliittisista kysymyksistä, sillä oli ollut oma tutkimusjaostonsa, ja lisäksi se oli teettänyt tilaustutkimusta. Komiteassa olivat edustettuina poliitikot, virkamiehet, työnantajat, työntekijät, aikuiskoulutusoppilaitokset ja aikuiskasvatustutkimus, ja osa sen jäsenistä edusti useaa toimintaa samanaikaisesti. Komiteatyön tuotoksia olivat muun muassa mietinnöt, joilla ohjattiin aikuiskoulutuspolitiikan tekoa.

Tutkimuksen ja politiikanteon suhteessa välittäjänä voisi toimia myös kokonaan oma organisaationsa. Aineisto sisälsi runsaasti pohdintaa mahdollisesta välittäjäorganisaatiosta, sillä AITURI-hankkeen nimenomainen tarkoitus oli kartoittaa rakenteellisten ratkaisujen tarvetta ja kerätä ratkaisuehdotuksia aikuiskasvatuksen tutkimuksen, käytännön ja politiikanteon suhteiden kehittämiseksi. Useat käytännön toimijat toivat esiin institutionaalisen välittäjän puutteen Suomessa. Kaikki aikuiskasvatuksen toimijat kattavan välittäjäorganisaation perustamista pidettiin kuitenkin jokseenkin mahdottomana, sillä toiminnot olivat eriytyneitä instituutioihin liittyvien asioiden, kuten rahoituksen, suhteen:

"Semmonen kokonaisvaltainen, missä ois kaikki, [--], siis semmonen foorumi on äärimmäisen vaikee ees kuvitella. [--] kun, sitä järjestetään niin paljon niin erityyppisissä paikoissa. [--] kun ne toiminnan lähtökohdat on niin erilaiset tavallaan ja rahotusvälineet on niin erilaiset [--] kun Suomessakaan ei oo hallinnollisesti semmosta kokoavaa, kuka sanois vaikka, että noniin, nyt kaikki aikuiskouluttajat, nyt me ollaan kiinnostuneita teidän asian yhteisestä kehittämisestä. Meillä ei oo ministeriössä semmosta, niin kun yhtä yksikköö, meil ei oo Opetushallituksessa semmosta." (H8:187-188).

Muutamat toimijat suhtautuivat uusien rakenteiden luomiseen periaatteellisen kriittisesti. Yksi vapaan sivistystyön toimija viittasi kuitenkin kansainvälisiin esimerkkeihin välittäjäorganisaatiosta. Hän pohti, olisiko Suomessa mahdollista perustaa samanlainen aikuiskoulutuksen tutkimus- ja kehittämisorganisaatio kuin Norjan silloinen VOX, jonka nimi on nykyisin Kompetance Norge, tai Englannin NIACE, joka on nykyisin Learning \& Work Institute:

"--] me ollaan aika pieni maa, meillä ei oo ehkä varaa semmosiin uusiin instituutioihin. Mut se pitää huomata, että joku meilt puuttuu. Ja muissa maissa se on ratkastu, että perustetaan tämmönen koulutus-kehittämislaitos." (H9:64).

Vaikka uudelle kansalliselle aikuiskoulutuksen tutkimus- ja kehittämisorganisaatiolle ei olisi resursseja, haastateltujen mukaan olisi mahdollista käynnistää "ajassa kestävämpi hanke" tai verkostomaisia toimintatapoja, joilla lisättäisiin tutkimuksen hyödyntämistä politiikanteossa ja käytännön toiminnassa. "Aikuiskoulutuksen verkostollakin" pitäisi silti olla jokin "neuvotteluelin", "kokoava yksikkö", "ydinryhmä", "koordinaatio" tai "solmukohta" huolehtimassa toimijoiden välisistä säännöllisistä kohtaamisista ja vuorovaikutuksesta ja tutkimuksen hyödyntämisestä. Ryhmäkeskusteluun osallistuneet käytännön toimijat pohtivat, että verkostomaisessa ratkaisussa vetovastuun voisi hajauttaa niin, että toimijat nimittäisivät kukin vastuuhenkilön tutkimusyhteyksien kehittämiselle. He ehdottivat vuorovaikutuksen lisäämistä uuden vuorovaikutusteknologian ja -foorumeiden avulla, mutta politiikantekijät epäilivät niitä foorumeilla esiintyvien haittailmiöiden vuoksi. Yksi politiikantekijä toivoi, että nimenomaan tutkijat esittäisivät uudenlaisia avauksia rakenteista tai projekteista, jotka vahvistaisivat politiikanteon tutkimusperusteisuutta, sillä tutkimus on lähtökohtaisesti autonomista. 
Ihmisestäkin voi tulla välittäjä tutkimuksen ja politiikanteon suhteeseen, jos hänellä on jonkinlainen kytkös molempiin toiminnan alueisiin. Haastatelluilla politiikantekijöillä, kuten myös erälllä käytännön toimijalla, oli kaksoisrooli, sillä he tekivät työnsä ohella väitöskirjatutkimusta. Yhdelle tutkijalle oli taasen muodostunut tilapäinen kaksoisrooli, kun hänet eräästä yhteiskunnallisesta aiheesta kirjoitettuaan oli kutsuttu osallistumaan politiikantekoprosessiin. Toimijat mielsivät, että kaksoisroolissa oppii tuntemaan molempia maailmoja, niiden kieltä ja ajankohtaisia keskusteluja. Kokemus sekä tutkimuksesta että politiikanteosta ei kuitenkaan automaattisesti tarkoittanut välittäjän roolin omaksumista ja käännösten tekemistä yhteisten intressien ja jaetun ymmärryksen löytämiseksi.

\section{Kielellistä ja kulttuurista kääntämistä}

Useat haastatellut ja ryhmäkeskustelijat sanoivat aikuiskasvatuksen toimijoiden vuorovaikutuksen, tutkimuksen hyödyntämisen ja tutkimusyhteistyön edellytykseksi "yhteisen kielen", "samankaltaisen kielen" tai "jaetun kielen" löytämisen. Ryhmäkeskustelijat mielsivät, että tutkimuksia pitäisi "suomentaa" ja "tehdä ymmärrettäväksi” politiikantekijöille ja käytännön toimijoille.

Puhe ilmensi ja tuotti mielikuvaa sellaisesta suhteiden ylläpitämiseen tarvittavasta työstä, jota ANTissa käsitteellistetään käännösten tekemisenä. Jaetun kielen koettiin lisäävän yhteisymmärrystä ja edistävän yhteistoimintaa, kuten aineistonäytteet politiikantekijän haastattelusta ja käytännön toimijoiden ryhmäkeskustelusta ilmentävät:

"Voisko sanoa, et saatais semmonen keskusteluyhteys, et puhutaan edes samaa kieltä, esitetään ne kysymykset samoilla ehdoilla, muotoillaan asiat samassa diskurssissa." (H3:106)

”[-- että tosiaankin löydettäis sitä yhteistä kieltä, jonka jälkeen vois sitten löytyä niitä uusia toimintamalleja." (K1:23).

Puheella kielistä ei ensisijaisesti tarkoitettu kansallisia kieliä ja suomen kielen asemaa tieteen kielenä englannin kielen hallitessa (ks. Heikkinen \& Tomperi 2018), vaikka niin sanottu kielikysymyskin aiheuttaa käännösten tarvetta. Sillä tarkoitettiin aikuiskasvatuksen tutkimuksen, politiikanteon ja käytännön toisistaan eroavia kulttuurisia kieliä käsitteineen.

Käytännön toimijoiden mukaan politiikanteon kieli ilmensi erilaisia arvostuksia aikuiskoulutuksen rahoitusta koskevassa argumentoinnissa. Muutamat käytännön toimijat toivoivat, että tutkijat auttaisivat heitä osoittamaan politiikantekijöille aikuiskoulutuksen arvon ja vaikuttavuuden käyttämällä talouden kieltä, jota politiikantekijät puhuvat, vaikka mielsivät tutkijoiden pitävän sivistystä itseisarvona. Tämän mielikuvan mukaan tutkijat voisivat siis vaihdella käyttämäänsä käsitteellistä kieltä kulloisenkin tarkoituksen mukaisesti.

Tiedeviestintää voidaan yhtä lailla pitää jaettua ymmärrystä edistävänä kääntämisenä. Sitä toivottiin lisättävän, jotta politiikantekijät ja käytännön toimijat tulisivat tietoiseksi "hyvästä tutkimuksesta", josta "ei pidetä kauheesti meteliä" (H11:57). Haastellut ja keskustelijat puhuivat popularisoinnista, mikä oli aineistonkeruuajankohtana yleisesti käytetty termi. Erityisesti sitä toivoivat käytännön toimijat, jotta tutkimustiedon omaksuminen olisi helpompaa. Moni toimija jakoi lisäksi sen mielikuvan, että politiikantekijät haluavat tutkimukselta vain nopeasti omaksuttavat ydinkohdat ja toteutettavissa olevia suosituksia politiikantekoa ohjaamaan. Yksi politiikantekijä kuitenkin painotti tiedon luotettavuutta tärkeämpänä kuin helppoa saatavuutta tai helppotajuisuutta.

Sen, että akateeminen tutkimus alkaisi sisältää rakenteellisesti enemmän vuorovaikutusta ja käännöksiä, sanottiin vaativan, että "tutkijayhteisön pitäis varmaan omia toimintakulttuureja käytännöllistää" (H10:162). Tutkijoiden suhtautuminen tutkimuskulttuurin muutosvaateeseen vaihteli. Yksi heistä toi esiin, että tarvelähtöisyys ja osallistaminen voivat kaventaa tutkimuksen autonomiaa. Sekä politiikantekijä että käytännön toimija mainitsivat, että myös tutkimuksen rahoituksen käytänteitä pitäisi kehittää, sillä pitkäkestoiset ja työläät hankerahoituksen hakuprosessit hankaloittavat tutkijoiden mahdollisuuksia valita ajankohtaisia tutkimusaiheita.

Ammatillisen aikuiskoulutuksen tutkijat taas jakoivat ryhmäkeskustelussa hyviä kokemuksiaan osallistavista tutkimusprosesseista. He käyttivät ANTin levittämis- ja käännösmalliin väljästi rinnastettavissa 


\section{TUTKIJOIDEN}

\section{SUHTAUTUMINEN}

\section{TUTKIMUSKULTTUURIN}

MUUTOSVAATEESEEN

\section{VAIHTELI.}

olevia Moodi 1 - ja Moodi 2 -käsitteitä (Gibbons, Limoges, Nowotny, Schwartzman, Scott \& Trow 1994) kuvaamaan tiedon tuottamisen paradigmaeroja joko eristäytymällä muista toimijoista tai yhteistoiminnallisesti ja painottivat hierarkioiden madaltamisen tarvetta toimijoiden välillä.

Eri taustoista tulevien toimijoiden osallistamisen tutkimusprosessiin ajateltiin mahdollistavan yhteisen kielen ja ymmärryksen rakentamista, jolloin käännöksiä tapahtuu jo tutkimusprosessin aikana eikä vasta sen lopussa. Sekä tutkijoilla, politiikantekijöillä että käytännön toimijoilla oli kokemuksia siitä, että tutkimusprojektit, tilaustutkimukset ja arvioinnit olivat olleet osallistavia. Yksi tutkija kertoi esimerkin, että osallistetuilta toimijoilta voidaan pyytää kommentteja projektissa tuotettaviin teksteihin jo kirjoitusvaiheessa. Toinen tutkija koki, että osallistaminen edisti tutkimuksen siirrettävyyttä ja hyödynnettävyyttä, mutta sen toteuttaminen ei välttämättä ollut tutkijoille helppoa:

”[--] meille tutkijoille on äärettömän vaikeeta tai ainakin ehkä mulle ja monille, ottaa niitä käytännön toimijoita mukaan, koska sillä tavalla se jatkuu, vuoropuhelu. [--] niin kyllä mun on vaikee vastata, kun joku valmentaja kysyy multa, että * [ $=$ henkilön nimi], että kun sulla on tollasia hienoja kaavioita, niin mitä ne tarkottaa käytännössä mun valmennustyössä, jos mulla ei ois ollu ne valmentajat mukana. [--] se on ehkä meidän tutkijoitten tässä niin kun tietyn jutun murtamisia ja nöyrtymistäkin vaativa." (K5:18).

Jäi kuitenkin epäselväksi, voiko tutkijoiden mielestä politiikantekijöitä osallistaa tutkimukseen samaan tapaan kuin käytännön toimijoita. Aineistosta ilmeni sekin, että jotkut tutkijat suhtautuvat varauksellisesti yhteistyöhön politiikantekijöiden kanssa. Mielikuvat siitä, että politiikantekijät odottavat evidenssin kaltaista tietoa tai valikoivat sitä intressiensä mukaan ja pyrkivät ohjaamaan tutkimusta, voivat muodostaa esteen osallistaa politiikantekijöitä tutkimukseen (ks. Väliverronen 2019).

ANTin mukaan vuorovaikutus on kuitenkin toimijuuden elinehto, ja tieteentekijöidenkin toimijuus ja kyky neuvotella intresseistä pikemminkin vahvistuu kuin heikentyy vuorovaikutuksessa ja voimien koetuksissa politiikantekijöiden kanssa. Tutkimuksen ja politiikanteon kollektiivien kokoonpanoilla on kuitenkin merkitystä, koska se, miltä asenteelliselta ja käsitteelliskielelliseltä etäisyydeltä vuorovaikutuksessa lähdetään liikkeelle, vaikuttaa käännösten tekemiseen tarvittavan työn määrän ja vuorovaikutuksen onnistumiseen.

\section{MIELIKUVISTA VUOROVAIKUTUKSEN KEINOJEN JA SUUNTIEN UUDELLEENTULKINTAAN}

Käyttämäni aineistot ilmensivät aikuiskasvatustoimijoiden mielikuvia tutkimuksen ja politiikanteon suhteesta ja vuorovaikutuksesta 2010-luvun alussa, jolloin aikuiskasvatuksen toimijat olivat käyneet keskustelua vuorovaikutuksen lisäämisen tarpeesta ja keinoista. Toimintaa ohjaavien mielikuvien tutkiminen näyttäytyi aiheellisena, sillä tutkimuksen ja politiikanteon vuorovaikutuksen lisäämistä pidettiin toivottavana vaan ei ongelmattomana.

ANTin valitut käsitteet - mustat laatikot, intressit, välittäjät ja käännökset - ohjasivat matkaoppaina analysoimaan tutkimuksen ja politiikanteon suhdetta sosio-materiaalisesti, eli erityisesti tutkimuksen ja politiikanteon vuorovaikutuksen ehtoja määrittävien instituutioiden ja vuorovaikusta edistävien välittyneiden käytäntöjen kannalta. Löydökset yhdessä muun tutkimuskirjallisuuden kanssa ovat omiaan lisäämään ymmärrystä käytettävissä olevan keinovalikoiman moninaisuudesta tutkimuksen ja politiikanteon vuorovaikutuksen lisäämiseksi.

Aineistossa ilmeni mielikuvia, joiden mukaan tutkimus ja politiikanteko elivät toisistaan erillään, kuin omissa mustissa laatikoissaan. Niiden suhde ei siten lähtökohtaisesti näyttäytynyt vuorovaikutussuhteena. Kuten aiemmassakin tutkimuksessa on todettu, suhteiden muodostamista haastavat paitsi tutkimuksen ja 
JOISSAKIN MIELIKUVISSA

\section{TUTKIMUS JA POLITIIKANTEKO}

\section{ELIVÄT TOISISTAAN}

\section{ERILL $\dddot{A} \dddot{A} N$, KUIN OMISSA \\ MUSTISSA LAATIKOISSAAN.}

politiikanteon merkittävästi erilaiset toimintakulttuurit (Locke 2009, 132) myös aikuiskasvatuksen tutkimuksen, politiikanteon ja käytännön sisäinen eriytyneisyys (Heikkinen 2007,73-81; 2005, 256; 2014, 215).

ANT-tutkijat ovat esittäneet, että tiedon rakentamisen ontologiat ovat niin erilaisia tutkijoilla, politiikantekijöillä ja alan ammattilaisilla, että voidaan oikeutetusti puhua erillisistä maailmoista, eikä mustista laatikoista sinänsä yritetä päästä eroon (Fenwick \& Edwards 2014). Suhteiden yksityiskohtaisempi analyysi kuitenkin osoitti, että toimintojen ja toimijoiden välillä on vuorovaikutusta. Vaikka siis erilaiset toimintakulttuurit tunnustetaan, tutkimus ja politiikanteko voivat silti päästä vuorovaikutukseen, kun tunnistetaan välittäjärakenteita, välittäviä toimintoja ja toimijoiden kyky toimia "sillanrakentajina" eli vuorovaikutuksen välittäjänä ja käännösten tekijöinä (Ginsburg, \& Gorostiaga 2001; Osborne 2004; Eriksson \& Sundelius 2005; Kontula 2020).

Aineistosta ilmeni, että näyttöön perustuva politiikanteko oli muodostunut diskursiiviseksi standardiksi (ks. Gorur 2010) aikuiskasvatustoimijoiden keskuudessa. Politiikantekijöiden miellettiin odottavan numeerista ja yleistettävissä olevaa näyttöä päätöksenteon perustaksi. Yhtäältä tutkimuksen hyödyntämisen miellettiin riippuvan politiikantekijöiden kiinnostuksesta ja asenteesta tiedettä ja tutkimusta kohtaan ja toisaalta tutkijoiden vaivannäöstä viestiä työstään. Samalla tutkimuksen hyödyntäminen oli jo kirjattu koulutushallinnon instituution strategiseksi toimintatavaksi (OPH 2010), joten politiikanteon tutkimusperusteisuus ei enää ollut vain yksilöiden vaan kollektiivien laajemmin jakama intressi.

Koska aiempi kasvatustieteellinen tutkimus on osoittanut ongelmalliseksi tavan määrittää tutkimuksen ja politiikanteon suhdetta tutkimuksen tuottaman näytön vaikuttavuutena politiikantekoon (esim. Hargreaves 1999; Lassnigg 2012, ks. yllä), on aiheellista edelleen pohtia aikuiskasvatustutkimukselle ominaisia keinoja tuottaa aikuiskasvatusta koskevaa tietoa politikanteossa hyödynnettäväksi.

Pohdinta on tarpeen siksikin, että aikuiskasvatustoimijoilla oli ristikkäisiä mielikuvia tutkijasta joko neutraalina tai poliittisesti orientoituneena toimijana tutkimuksen ja politiikanteon vuorovaikutuksessa. Edes näytöksi miellettävää tutkimusta ei voi erottaa arvoista, mistä suomalaisena esimerkkinä on vahva koulutuksellisen tasa-arvon ihanne (Niemi 2017,45; Biesta 2007, 2010). Aikuiskasvatustutkimus on siten väistämättä poliittista ja normatiivista (Heikkinen 2005, 281). Siispä tutkimuksen tulisi tuottaa tietoa ennen kaikkea kasvatusta koskevista arvoista: siitä, mitä kasvatuksessa pidetään toivottavana ja kasvatuksen perimmäisinä päämäärinä (Biesta 2007, 17; Bridges and Watts 2008; Biesta 2016, 202; Krejsler 2017,23). Se taas edellyttäisi paitsi tutkimusmenetelmien moninaisuutta (Dumas \& Anderson 2014), myös filosofisia, sosiologisia ja historiallistavia tutkimusotteita, mikä monipuolistaisi mielikuvia politiikanteossa hyödynnettävissä olevasta tutkimuksesta.

ANTin välittäjä-käsitteen ohjaamana aineistosta tehtiin löydöksiä tutkimuksen ja politiikanteon suhdetta välittävistä elementeistä, jotka toimijoiden mukaan edistivät vuorovaikutusta. Näitä olivat muun muassa tutkimus- ja kehittämisprojektit, projekteina toteutettavat tilaustutkimukset ja arvioinnit sekä tutkimuskonferenssit ja -seminaarit. Tutkimuksen tekeminen projekteina näyttäytyi tässä aineistossa siten myönteisessä valossa. Projekteihin on aiemminkin nähty sisältyvän transformatiivista potentiaalia, mutta samalla projekteilla johtaminen voi olla hallinnan keino politiikanteossa, ja projektit voivat korvata demokraattisempia tiedon tuotannon tapoja (Heikkinen 2004).

Tutkimuksen yhteiskunnallista vaikuttavuutta on edelleen pyritty vahvistamaan 2010-luvulla esimerkiksi Suomen Akatemian strategisen tutkimuksen neuvoston (STN) sekä säätiöiden ja seurojen, kuten Suomen Kulttuurirahaston ja Suomalaisen Tiedeakatemian, rahoituksilla, minkä vuoksi tutkijat muotoilevat tieteen tekoa enenevässä määrin yhteiskuntaa muuttaviksi ohjelmiksi ja projekteiksi. Aineiston mu- 
AiKUiskasvatusta

KOSKEVAAN JATKUVAN

OPPIMISEN UUDISTUKSEEN

OSALLISTETAAN LAAJASTI

YHTEISKUNNAN ERI

TOIMIJARYHMI $\ddot{A}$.

kaan projektit olivat olleet merkityksellisiä eritoten siksi, että ne olivat mahdollistaneet toimijoiden tapaamisen ja keskustelemisen toistensa kanssa projektien tilaisuuksissa ja raportteja yhdessä työstäessään, ei niinkään tulostensa vaikuttavuuden vuoksi.

Tiedelehdet näyttäytyivät aineistossa hybrideinä välittäjinä. Niiden on aiemmissakin tutkimuksissa tunnistettu paitsi kuuluvan aikuiskasvatuksen toimijaverkkoon myös aktiivisesti muokkaavan sitä vaikuttaessaan tutkijoiden kollektiivien muodostumiseen ja märittäessään aikuiskasvatustietoa (Zukas 2009; Larsson 2010; ks. myös Väliverronen 2019, 4). Suomalaisille aikuiskasvatustieteilijöille julkaisu näyttäytyi vuorovaikutusalustana, ja avoin julkaiseminen näkyy entisestään parantavan mahdollisuutta käyttää lehteä tutkimuksen ja politiikanteon vuorovaikutuksen lisäämiseen.

Aikuiskasvatustoimijat toivat esiin, että aiempina vuosikymmeninä tutkimuksen ja politiikanteon vuorovaikutusta oli rakenteistettu nykyistä vahvemmin ministeriötasolla aikuiskoulutuskomitean, aikuiskoulutus- ja elinikäisen oppimisen neuvoston työhön (ks. Tuomisto 2014). Välittäjärakenteiden purkaminen vei tutkimuksen ja politiikanteon toimijoilta keinoja jatkuvaan vuorovaikutukseen ja tiedon jaettuun tuottamiseen sekä tutkijoiden asiantuntijatiedon monipuoliseen hyödyntämiseen, joita politiikkalähtöisen hallitun evidenssitiedon tuottaminen ei voi kokonaan korvata (Heikkinen 2004). Useimmat aikuiskasvatustoimijat pitivät tarpeellisena perustaa uusi välittäjärakenne politiikanteon tutkimusperusteisuuden ja toimijoiden vuorovaikutuksen vahvistamiseksi, mutta näkemykset välittäjän organisatorisesta muodosta ja sijainnista vaihtelivat.

ANTin käännösten käsitteen ohjaamana tehtiin löydöksiä aikuiskasvatuksen toimijoiden mielikuvis- ta, joiden mukaan tutkimuksen ja politiikanteon vuorovaikutuksessa tärkeää on rakentaa yhteistä ymmärrystä yli käsitteellisten ja kulttuuristen kielten erilaisuuden. Aikuiskasvatuksen toimijat esittivät vuorovaikutuksen lisäämisen keinoksi popularisointia. Nykyisin puhutaan pikemminkin tarpeesta lisätä yleistajuista tiedeviestintää tutkimuksesta, ja siihen ovat myös tutkijat kannustaneet toisiaan (Vaattovaara 2013, 24-28; Väliverronen 2016, 127-128). Päätöksentekoa koskevien tiedontarpeiden ei kuitenkaan ajateltu täyttyvän popularisoiduilla teksteillä. Lisäksi popularisointi voi olla melko passiivista tiedon välittämistä eikä vuorovaikutusta (Knott \& Wildavsky 1991, 222). Siksi popularisointi voi ainoastaan tukea muita keinoja lisätä tutkimuksen ja politiikanteon vuorovaikutusta.

Toimijoiden ajatukset siitä, että tutkimuksen kulttuurin tulisi muuttua entistä avoimemmaksi ja osallistavammaksi, ilmensivät ANTin käsitteitä käyttäen, että tieteenteossa tulisi siirtyä levittämismallista käännösmalliin. Toimijoilla oli kokemuksia osallistamisesta, ja sitä pidettiin aiemman tutkimuksen tavoin keinona lisätä vuorovaikutusta. Siten se edisti tutkimuksen hyödynnettävyyttä ja vaikuttuvuutta (esim. Edwards 2012). Aineisto tarjosi lisäksi sen näkökulman, että osallistamista voi toteuttaa niinkin, että tutkija osallistetaan politiikantekoprosessiin.

2020-luvun taitteessa diskurssi politiikanteon tutkimusperusteisuudesta on edelleen voimistunut, ja esimerkiksi aikuiskasvatusta koskevaan jatkuvan oppimisen uudistukseen osallistetaan laajasti yhteiskunnan eri toimijaryhmiä. Uudistuksen valmistelussa tutkimusta kuitenkin näytetään hyödynnetyn melko perinteisillä keinoilla. Opetus- ja kulttuuriministeriö sekä ohjelmaa fasilitoinut Sitra ovat teetättäneet selvityksiä ja tehneet kyselyn uudistuksen keskeisistä teemoista (VN 2019b; Sitra 2020) sekä järjestäneet tilaisuuksia kuullakseen tutkijoita aikuisten kouluttautumisesta, oppimisesta ja osaamisen kehittämisestä tekemästään tutkimuksesta (OKM 2019b; Sitra 2019). Ovatko keinot riittäviä tutkimuksen ja politiikanteon jatkuvan vuorovaikutuksen ylläpitämiseen ja yhteistä ymmärrystä lisäävien käännösten tekemiseen? Vuorovaikutuksen keinovalikoimaa voisi laajentaa esimerkiksi tiedeneuvonannon käytännöil- 
lä (Kuosmanen \& Sivonen 2020). Myös uudistuksen perimmäisiä arvoja ja päämääriä voitaisiin kirkastaa tutkimukseen perustuvan vuorovaikutuksen keinoin.

Aikuiskasvatustoimijoiden mielikuvien valaiseminen toimijaverkkoteorian käsitteiden avulla tuotti siis löydöksiä ja uudelleentulkintoja, joiden mukaan tutkimusta voidaan tuottaa politiikanteossa hyödyntämistä varten erityisesti arvokeskustelua tukemaan. Vieläkin paremmin vuorovaikutusta edistettäisiin jo olemassa olevia välittäjiä hyödyntämällä, mahdollisesti uusia rakentamalla sekä jaettua ymmärrystä lisääviä käännöksiä tekemällä.

Tutkimusasetelmassa tehtyjen rajausten vuoksi huomio tutkimuksen ja politiikanteon suhteesta keskittyi nimenomaan tutkimuksen ja politiikanteon toimintojen ja toimijoiden vuorovaikutukseen ja sen rakentumiseen, vaikka aineistokin antoi viitteitä siitä, että tutkimuksen ja politiikanteon vuorovaikutuksen toimivuus on merkityksellistä erityisesti aikuiskasvatuksen moninaisten käytäntöjen kannalta. Politiikanteon kanssa vuorovaikutukseen pyrkivän tutkimustoiminnan suunta voi siis yhtä hyvin olla aikuiskasvatustutkimukselle ominaisesti aikuiskasvatuksen käytännöt kuten myös julkinen keskustelu, joista käännösketjuja jatkettaisiin edelleen politiikanteon suuntaan. Tutkijat ovatkin rohkaisseet toisiaan osallistumaan julkiseen keskusteluun, tuomaan tieteen ulos instituutiosta ja kyseenalaistamaan tiedon omistajuutta yhteistutkimuksen menetelmin (Jarvis 2010, 268, Dumas \& Anderson 2014; Vähämäki 2010; Heikkinen 2012).

Toimijoita laajasti osallistavaa tutkimukseen perustuvaa vuorovaikutusta tarvitaan erityisesti yhteiskun- tien kestävyyttä koettelevien suurten kysymysten, kuten ilmastonmuutoksen, eriarvoisuuden lisääntymisen ja talouskriisin, käsittelyyn, jotta ratkaisuehdotuksia niihin tulee useita rihmastoja (Latour 1999b, 15) pitkin politiikantekoprosesseihin laajasti jaettuina intresseinä ja asioina, joilla on väliä ja joita asettua puolustamaan (Fenwick \& Edwards 2014; Heikkinen 2014; Trencher ym. 2014; Latour 2004, 2017).

Aikuiskasvatuksen tutkijat ovat tyypillisesti sekä tieteen että yhteiskuntaelämän moniottelijoita. He voivat olla avainasemassa luomassa uusia välityksiä tutkimuksen, politiikanteon ja käytäntöjen välille ja kääntämässä erilaisten toimijoiden intressejä yhteistutkimukseen ja yhteiskunnallista muutosta tuottavaan yhteistoimintaan. Koska toisten toimijoiden intressien kääntäminen ja yhteiskunnan muuttamiseen tähtäävä toiminta on itse asiassa politiikantekoa (Ylikoski 2000, 302), tutkimuksen ja politiikanteon samankaltaisuuksia ja lopulta jäljelle jääviä eroavaisuuksia tulisi reflektoida ja selventää olennaisena osana vuorovaikutusta.

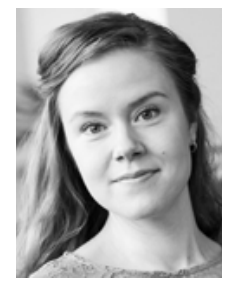

SINI TERÄSAHDE

KM, väitöskirjatutkija kasvatustieteiden ja kulttuurin tiedekunta

Tampereen yliopisto

(iD https://orcid.org/0000-00029359-8990

Osoitan kiitokseni artikkelia eteenpäin vieneestä kommentoinnista emeritaprofessori Anja Heikkiselle, vertaisarvioitsijoille ja toimitukseen osallistuneille henkilöille.

\section{LÄHTEET}

Alastalo, M., Kunelius, R., \& Muhonen, R. (2014). Evidenssiä eliitille ja kansainvälistä huipputiedettä? Tutkimuksen vaikuttavuuden mielikuvastot tiedepolitiikan resursseina. Teoksessa R. Muhonen \& H.-M. Puuska (toim.) Tutkimuksen kansallinen tehtävä. Tampere: Vastapaino, 119-149.

Alasuutari, P. \& Qadir, A. (2016). Imageries of the Social World in Epistemic Governance. International Sociology 31(6), 633-652. https://doi. org/10.1177/0268580916662386

Biesta, G. (2007). Why "What Works" Won't Work: Evidence-Based Practice and the Democratic Deficit in
Educational Research. Educational Theory 57(1), 1-22. https://doi.org/10.1111/j.1741-5446.2006.00241.x

Biesta, G. (2010). Why 'What Works' Still Won't Work: From Evidence-Based Education to Value-Based Education. Studies in Philosophy and Education 29(5), 491-503. https://doi.org/10.1007/s11217010-9191-x

Biesta, G. (2016). Improving Education through Research? From Effectiveness, Causality and Technology, to Purpose, Complexity and Culture. Policy Futures in Education 14(2), 194-210. https://doi. org/10.1177/1478210315613900 
Birnbaum, R. (1988). How colleges work. The Cybernetics of Academic Organization and Leadership. San Francisco: Jossey-Bass Publishing.

Bridges, D. \& Watts, M. (2008). Educational Research and Policy: Epistemological Considerations. Journal of Philosophy of Education 42(S1), 41-62. https://doi. org/10.1111/j.1467-9752.2008.00628.x

Callon, M. \& Latour. B. (1981). Unscrewing the Big Leviathan: How Actors Macro-structure Reality and how Sociologists Help Them to Do so. Teoksessa K. Knorr-Cetina \& A. V. Cicourel (toim.) Advances in Social Theory and Methodology. Towards an Integration of Micro- and Macro-sociologies. Boston: Routledge \& Kegan Paul, 277-304.

Dumas, M. J. \& Anderson G. (2014). Qualitative Research as Policy Knowledge: Framing Policy Problems and Transforming Education from the Ground up. Education Policy Analysis Archives 22(1), 1-20. http:// dx.doi.org/10.14507/epaa.v22n11.2014

Edwards, A. (2012). User Engagement and the Process of Educational Research. Teoksessa T. Fenwick \& L. Farrell (toim.) Knowledge Mobilization and Educational Research, 44-58. New York: Routledge.

Engeström, Y. (2004). Ekspansiivinen oppiminen ja yhteiskehittely työssä. Tampere: Vastapaino.

Eskola, A. (2019). Vanhanakin voi ajatella: Mielikuvista ja niiden voimasta. Tampere: Vastapaino.

Eriksson, J., \& Sundelius, B. (2005). Molding Minds That Form Policy: How to Make Research Useful. International Studies Perspectives 6(1), 51-71. https:// doi.org/10.1111/j.1528-3577.2005.00193.x

Fenwick, T. \& Edwards, R. (2014). Networks of Knowledge, Matters of Learning, and Criticality in Higher Education. Higher Education 67(1) 35-50. https://doi.org/10.1007/s10734-013-9639-3

Gibbons, M., Limoges, C., Nowotny, H., Schwartzman, S. Scott, P. \& Trow, M. (1994). The New Production of Knowledge: The Dynamics of Science and Research in Contemporary Societies. London: Sage.

Ginsburg, M. B. \& Gorostiaga, J. M. (2001). Relationships between Theorists/Researchers and Policy Makers/ Practitioners: Rethinking the Two-Cultures Thesis and the Possibility of Dialogue. Comparative Education Review, 45(2), 173-196. https://doi. org/10.1086/447660

Gorur, R. (2010). Policy Assemblage in Education. Väitöskirja. Melbourne Graduate School of Education. Melbourne: The University of Melbourne.

Hargreaves, D. H. (1999). Revitalising Educational Research: Lessons from the Past and Proposals for the Future. Cambridge Journal of Education 29(2), 239-249. https://doi. org/10.1080/0305764990290207

Heikkinen, A. (2004). Evaluation in the Transnational 'Management by Projects' Policies. European
Educational Research Journal 3(2), 486-500. https:// doi.org/10.2304/eerj.2004.3.2.4

Heikkinen, A. (2005). Aikuiskasvatuksen missiot ja työnjako. Teoksessa A. Heikkinen (toim.) Aikuiskasvatuksen tutkimuspolut. Helsinki: Kansanvalistusseura, 255-286.

Heikkinen, A. (2007). Fragmentation of Adult Education Research. Teoksessa R. Rinne, A. Heikkinen \& P. Salo (toim.) Adult Education - liberty, fraternity, equality? Nordic Views on Lifelong Learning. Turku: Suomen kasvatustieteellinen seura, 68-84.

Heikkinen, A. (2012). A-luokan aikuiskasvatustiedettä. Aikuiskasvatus 32(1), 50-58. https://doi.org/10.33336/ aik.93969

Heikkinen, A. (2014). Aktivismista realismiin - ihmisja yhteiskuntakeskeisen aikuiskasvatuksen/ aikuiskasvatustieteen kritiikki. Aikuiskasvatus 34(3), 215-223. https://doi.org/10.33336/aik.94101

Heikkinen, A. Pätäri, J. \& Teräsahde, S. (2019). Disciplinary Struggles in and between Adult, Vocational and General Education in the Academy: Lessons from Finland. Teoksessa A. Heikkinen, J. Pätäri \& G. Molzberger (toim.) Disciplinary Struggles in Education. Tampere: Tampere University Press, 83-115. http://urn. fi/URN:NBN:fi:tuni-201906262258

Heikkinen A. \& Teräsahde S. (2011). Aikuiskasvatus on tutkimisen ja asiantuntemuksen arvoinen. Aikuiskasvatuksen tutkimusyhteistyön rakenteelliset innovaatiot (AITURI) -hankkeen loppuraportti. Tampere: Tampereen yliopisto. http://urn.fi/ urn:isbn:978-951-44-8528-2

Heikkinen, H. L. T. \& Tomperi, T. (2018). Mitä pitäisi ajatella (suomen) kielestä (kasvatus)tieteessä? Kasvatus 49(2), 167-175. https://ktl.jyu.fi/fi/julkaisut/kasvatus/ kasvatus_2_2018_heikkinen-tomperi.pdf (9.11.2020).

Jarvis, P. (2010). Adult Education and Lifelong Learning: Theory and Practice (4. painos). London: Routledge.

Knott, J. \& Wildavsky, A. (1991). If Dissemination is the Solution, What Is the Problem? Teoksessa D. S. Anderson \& B. J. Biddle (toim.) Knowledge for Policy: Improving Education through Research, 214-224. London: The Falmer Press.

Kontula, A. (2020). Tutkija ja poliitikko - voiko roolit yhdistää? Tieteessä tapahtuu 38(2), 1-2. https:// journal.fi/tt/article/view/91543/50436 (20.10.2020).

Krejsler, J. B. (2017). Capturing the 'Evidence' and 'What Works' Agenda in Education: A Truth Regime and the Art of Manoeuvring Floating Signifiers. Teoksessa M.Y. Eryaman \& B. Schneider (toim.) Evidence and Public Good in Educational Policy, Research and Practice. Educational Governance Research 6. Switzerland: Springer, 21-41. https://doi.org/10.1007/978-3-31958850-6_2

Kuosmanen, J. \& Sivonen, M. H. (2020). Tiedeneuvonta poliittisen päätöksenteon tukena. Tieteessä 
tapahtuu 1/2020, 14-20. https://journal.fi/tt/article/ view/89791/49055 (11.3.2020).

Lampinen, O. (2002). Yhteiskuntatieteellisen tutkimuksen asema hallinnossa ja päätöksenteossa. Tiedepolitiikka 2/02, 15-22.

Larsson, S. (2010). Invisible Colleges in the Adult Education Research World. European Journal for Research on the Education and Learning of Adults 1(1-2), 97-112. https://doi.org/10.3384/rela.2000-7426.rela0010

Lassnigg, L. (2012). 'Use of Current Best Evidence': Promises and Illusions, Limitations and Contradictions in the Triangle of Research, Policy and Practice. International Journal of Training Research 10(3), 179203. https://doi.org/10.5172/ijtr.2012.10.3.179

Lassnigg, L. (2016). Complexity in a BureaucraticFederalist Education System. Teoksessa T. Burns \& F. Köster (toim.) Governing Education in a Complex World. Paris: OECD, 115-138. http://dx.doi. org/10.1787/9789264255364-en

Latour, B. (1984). The Powers of Association. Teoksessa J. Law (toim.) The Sociological Review Monograph 32, Power, Action and Belief. A New Sociology of Knowledge? London: Routledge \& Kegan Paul, 264280. http://www.bruno-latour.fr/sites/default/files/19POWERS-ASSOCIATIONS-GBpdf.pdf (21.2.2020).

Latour, B. (1987). Science in Action. How to Follow Scientist and Engineers through Society. Cambridge: Harvard University Press.

Latour, B. (1988). The Pasteurization of France. Käänt. A. Sheridan \& J. Law. Cambridge: Harvard University Press.

Latour, B. (1993). We Have Never Been Modern. Käänt. C. Porter. Nous n'avons jamais été modernes - essai d'anthropologie symétrique 1991. Cambridge: Harvard University Press.

Latour, B. (1996a). Aramis or the Love of Technology. Käänt. C. Porter. Aramis, ou l'amour des techniques 1993. Cambridge (Mass.): Harvard University.

Latour, B. (1996b). On Actor-Network Theory: A Few Clarifications. Soziale Welt 47(4), 369-381. http:// www.jstor.org/stable/40878163 (20.3.2020).

Latour, B. (1999a). Pandora's Hope: Essays on the Reality of Science Studies. Cambridge: Harvard University Press.

Latour, B. (1999b). On Recalling ANT. Teoksessa J. Law \& J. Hassard (toim.) Actor-Network Theory and After. Oxford: Blackwell, 15-25. https://doi.org/10.1111/ j.1467-954X.1999.tb03480.x

Latour, B. (2004). Why Has Critique Run out of Steam? From Matters of Fact to Matters of Concern. Critical Inquiry 30(2), 225-248. https://doi. org/10.1086/421123

Latour, B. (2005). Reassembling the Social: An Introduction to Actor-Network-Theory. Oxford: Oxford University Press.
Latour, B. (2017). Facing Gaia. Eight Lectures on the New Climatic Regime. C. Porter (Kääntäjä). Face à Gaïa. Huit conférences sur le nouveau régime climatique 2015. Cambridge; Medford: Polity Press.

Lehtonen, T. (2015). Aineellinen yhteisö. Helsinki: Tutkijaliitto.

Locke, W. (2009). Reconnecting the Research-PolicyPractice Nexus in Higher Education: 'Evidence-Based Policy' in Practice in National and International Contexts. Higher Education Policy 22(2), 119-140. http://dx.doi.org/doi:10.1057/hep.2008.3

Lubienski, C., Scott, J., \& DeBray, E. (2014). The Politics of Research Production, Promotion, and Utilization in Educational Policy. Educational Policy 28(2), 131-144 https://doi.org/10.1177/0895904813515329

Manninen, J. (2004). Mielikuvat ohjaavat aikuisten osallistumista koulutukseen. Aikuiskasvatus 24(3), 196-205. https://doi.org/10.33336/aik.93565

McLaughlin, T. (2000). Philosophy and educational policy: possibilities, tensions and tasks. Journal of Education Policy 15(4), 441-457. https://doi. org/10.1080/026809300413446

Michael, M. (2017). Actor-Network Theory. Trials, Trails and Translations. London: Sage.

Muhonen, R., Benneworth, P. \& Olmos-Peñuela, J. (2019). From Productive Interactions to Impact Pathways: Understanding the Key Dimensions in Developing SSH Research Societal Impact. Research Evaluation, rvz003. https://doi.org/10.1093/reseval/rvz003

Ness, E. C., \& Gándara, D. (2014). Ideological Think Tanks in the States: An Inventory of Their Prevalence, Networks, and Higher Education Policy Activity. Educational Policy 28(2), 258-280. https://doi. org/10.1177/0895904813515328

Niemi, H. (2017). What Is Evidence Required for and Who Generates That Evidence in the Finnish Educational System? Teoksessa M.Y. Eryaman \& B. Schneider (toim.) Evidence and Public Good in Educational Policy, Research and Practice. Educational Governance Research 6. Cham: Springer, 43-62. https://doi. org/10.1007/978-3-319-58850-6_3

Nurmi, K. \& Kontiainen, S. (2000). Aikuiskoulutuksen vaikuttavuus. Teoksessa R. Raivola (toim.) Vaikuttavuutta koulutukseen. Suomen Akatemian koulutuksen vaikuttavuusohjelman tutkimuksia. Helsinki: Edita, 29-50. http://www.aka.fi/globalassets/ awanhat/documents/tiedostot/julkaisut/vaikuttavuuttakoulutukseen.pdf (10.9.2020).

Nyman, G. (2015). University-Business-Government Collaboration: From institutes to platforms and ecosystems. Triple helix 2(2), 1-20. https://doi. org/10.1186/s40604-014-0014-x

OECD (2007). Evidence in Education. Linking Research and Policy. OECD Publishing, Paris. http://dx.doi. org/10.1787/9789264033672-en 
OKM (2019a). Jatkuva oppiminen. Verkkosivu. https:// minedu.fi/jatkuva-oppiminen (21.2.2020).

OKM (2019b). Tutkijatapaaminen jatkuvasta oppimisesta. Verkkosivu. https://minedu.fi/tutkijatapaaminen (1.4.2020).

OPH (2010). Opetushallituksen tutkimusstrategia 20102015. Muistio 2010:1. Helsinki: Opetushallitus.

Osborne, T. (2004). On Mediators: Intellectuals and the Ideas Trade in the Knowledge Society. Economy and Society 33(4), 430-447. https://doi. org/10.1080/0308514042000285224

Pantzar, E. (2007). Aikuiskasvatuksen toimintakentät. Teoksessa K. Collin \& S. Paloniemi (toim.) Aikuiskasvatus tieteenä ja toimintakenttinä. Jyväskylä: PS-kustannus, 17-54.

Pawson, R. (2006). "Evidence-Based Policy: The Promise of Systematic Review." Teoksessa R. Pawson EvidenceBased Policy: A Realist Perspective. London: Sage, 2-16. https://doi.org/10.4135/9781849209120.n1

Scott, P. (1999). The Research-Policy Gap. Journal of Education Policy (14)3, 317-337. https://doi. org/10.1080/026809399286378

Sitra (2019). Elinikäistä oppimista uudistetaan tutkimustietoa hyödyntäen. Yhteenveto jatkuvan oppimisen uudistukseen liittyvästä tutkijatapaamisesta. Julkaistu 29.11.2019. https://www.sitra.fi/artikkelit/ elinikaista-oppimista-uudistetaan-tutkimustietoahyodyntaen/ (21.2.2020).

Sitra (2020). Osaamisen aika. Julkaisut. Verkkosivu. https://www.sitra.fi/aiheet/osaamisen-aika/\#julkaisut (1.4.2020).

Spaapen, J. \& van Drooge, L. (2011). Introducing "Productive Interactions" in Social Impact Assessment. Research Evaluation 20(3), 211-218. https://doi.org/10 .3152/095820211x12941371876742

Suoranta, J., Kauppila, J. \& Salo, P. (2008). Aikuiskasvatuksen tieteellistyminen. Teoksessa J. Suoranta, J. Kauppila, H. Rekola, P. Salo \& M. Vanhalakka-Ruoho (toim). Aikuiskasvatuksen risteysasemalla: Johdatus aikuiskasvatukseen (2. uudistettu painos). Joensuu: Joensuun yliopisto.

Teräsahde, S. (tulossa). Actor-Network Theory Approach to Studying the Imageries of the Relations of Research, Practice and Policymaking in Adult Education. Väitöskirjan käsikirjoitus. Kasvatustieteiden ja kulttuurin tiedekunta. Tampereen yliopisto.

Thompson, T. L. (2015). Actor Network Theory and Adult Education. Elm Magazine 1/2015. https:// elmmagazine.eu/articles/actor-network-theory-andadult-education/ (30.5.2019).

Trencher, G., Yarime, M., McCormick, K.B., Doll, N.H \& Kraines, S.B. (2014). Beyond the Third Mission: Exploring the Emerging University Function of CoCreation for Sustainability. Science and Public Policy 41 (2), 151-179. https://doi.org/10.1093/scipol/sct044
Tuomisto, J. (2014). Suunnittelukeskeisen aikuiskoulutuspolitiikan arkkitehdit: Aulis Alanen ja Veli Lehtinen. Teoksessa K. Kantasalmi \& M. Nest (toim.) Valistajia, sivistäjiä, poliitikkoja ja asiantuntijoita. Tampere: Tampere University Press, 305-340. http:// urn.fi/URN:NBN:fi:uta-201706051815

Usher, R. \& Bryant, I. (1989). Adult Education as Theory, Practice and Research: Captive Triangle. Lontoo: Routledge.

Vaattovaara, J. (2013). Tutkijan identiteetit. Teoksessa U. Strellman \& J. Vaattovaara (toim.) Tieteen yleistajuistaminen. Helsinki: Gaudeamus, 23-31.

VN (2019a). Pääministeri Sanna Marinin hallituksen ohjelma 10.12.2019. OSALLISTAVA JA OSAAVA SUOMI - sosiaalisesti, taloudellisesti ja ekologisesti kestävä yhteiskunta. Valtioneuvoston julkaisuja 2019:31. Helsinki: Valtioneuvosto. http://julkaisut.valtioneuvosto. fi/bitstream/handle/10024/161931/NN_2019_31. pdf? sequence=1\&isAllowed=y (15.3.2020).

VN (2019b). A Study on Structures to Support Continuous Learning - International Benchlearning. O. Oosi, M. Koramo, N. Korhonen, A-M Järvelin, T. Luukkonen, J. Tirronen, L. Jauhola. Valtioneuvoston selvitys- ja tutkimustoiminnan julkaisusarja 18/2019. http://julkaisut.valtioneuvosto.fi/bitstream/ handle/10024/161392/18-2019\%20Jatkuvan \%20 oppimisen\%20rakenteet\%20raportti\%202.pdf (1.4.2020).

Vähämäki, J. (2010). Tieto ulos instituutiosta. niin \& näin 4/2010, 115-119. http://netn.fi/node/4473 (20.3.2020).

Väliverronen, E. (2016). Julkinen tiede. Tampere: Vastapaino.

Väliverronen, E. (2019). Tieteen vapauden ja tutkijan sananvapauden ongelmat yhä näkyvämpiä. Tieteessä tapahtuu 4/2019, 3-8. https://journal.fi/tt/article/ view/82811/41988 (11.3.2020)

Ylijoki, O.-H., Lyytinen, A. \& Marttila, L. (2011). Different research markets: a disciplinary perspective. Higher Education 62(6), 721-740. https://doi.org/10.1007/ s10734-011-9414-2

Ylikoski, P. (2000). Bruno Latour ja tieteentutkimus. Tiede \& edistys 25(4), 296-309.

Yliopistolaki 24.7.2009/558. Finlex. https://www.finlex.fi/fi/ laki/ajantasa/2009/20090558 (11.3.2020).

Zanten, van, A. (2006). Evidence and Policy in Education: a complex relationship. Teoksessa T. Schuller, W. Jochems, L. Moos \& A. Van Zanten (toim.) Evidence and Policy Research. EERJ Roundtable. European Educational Research Journal, 5(1), 57-70. https://doi. org/10.2304\%2Feerj.2006.5.1.57

Zukas, M. (2009). Editors, Journals and the Education of Adults: Actors and Actor-Networks. Studies in the Education of Adults 41(1), 1-5. https://doi.org/10.1080 /02660830.2009.11661569 


\section{LIITTEET}

Liite 1. Avainhenkilöhaastattelut ja keskustelutilaisuudet.

\begin{tabular}{|c|c|c|}
\hline Aineisto & $\begin{array}{l}\text { Ensisijainen } \\
\text { toiminta }\end{array}$ & Tehtävänimike \\
\hline \multirow{11}{*}{ 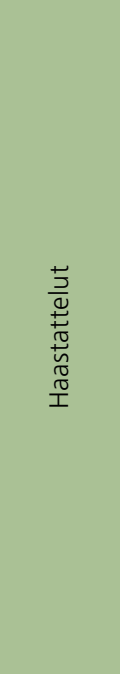 } & Tutkimus & aikuiskasvatuksen professori \\
\hline & Tutkimus & erityissuunnittelija, Koulutuksen arviointisihteeristö (tutkija) \\
\hline & Politiikanteko & opetusneuvos \\
\hline & Tutkimus & aikuiskasvatuksen professori emeritus \\
\hline & Käytäntö & työväenopiston rehtori \\
\hline & Käytäntö & ammattiliiton koulutusosaston osastopäällikkö ja kansanopiston rehtori \\
\hline & Politiikanteko & opetusneuvos \\
\hline & Käytäntö & kansainvälisten asioiden koordinaattori aikuis- ja ammattiopistossa \\
\hline & Käytäntö & vapaan sivistystyön yhteisjärjestön toiminnanjohtaja \\
\hline & Käytäntö & $\begin{array}{l}\text { toimitusjohtaja, aikuiskoulutuksen kehittämisyhtiö ja aikuiskoulutuksen } \\
\text { kansainvälinen kehittämisyhtiö }\end{array}$ \\
\hline & Käytäntö & kehittämispäällikkö yliopistossa \\
\hline \multirow{8}{*}{ 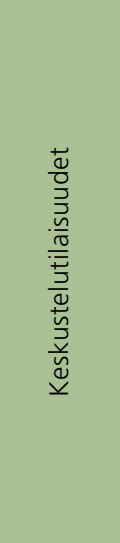 } & Käytäntö & Kasvatustieteilijäpäivä, SPECIA \\
\hline & Käytäntö & Vapaan sivistystyön ajankohtaispäivät, VSY \\
\hline & Käytäntö & Ajantasaseminaari, $\mathrm{KOL}$ \\
\hline & $\begin{array}{l}\text { Tutkimus (+ politiikan- } \\
\text { teko \& käytäntö) }\end{array}$ & European research triennial conference, ESREA \\
\hline & Tutkimus (+ käytäntö) & Ammattikasvatuksen ja ammatillisen koulutuksen tutkimuspäivät, OTTU \\
\hline & Tutkimus & Kasvatustieteen päivät, FERA \\
\hline & Tutkimus (+ käytäntö) & $\begin{array}{l}\text { 3rd TQF Research Seminar, VET\&Culture network -tutkimusverkosto, } \\
\text { Tampereen yliopisto }\end{array}$ \\
\hline & Käytäntö (+ tutkimus) & Vapaan sivistystyön kehittämispäivät, VST \\
\hline
\end{tabular}

\section{Instituutioiden lyhenteet}

ESREA The European Society for Research on the Education of Adults

FERA Suomen kasvatustieteellinen seura

KOL Kansalaisopistojen liitto

OTTU Ammatillisen koulutuksen tutkimusseura ry

SPECIA Asiantuntijat ja esihenkilöt ry

VST Vapaa sivistystyö ry

VSY Vapaan sivistystyön yhteisjärjestö ry 